\title{
Preparation and Characterization of Monoclonal Antibodies Suitable for Detection of Foodborne Pathogens by Biosensor
}

\section{ZHANG, Xiao-guang}

College of Food Science and Engineering, Jilin University | Laboratory of Food Hygienic Chemistry, Division of Food Science and Biotechnology, Department of Bioscience and Biotechnology, Graduate School of Bioresource and Bioenvironmental Sciences, Kyushu University | Laboratory of Food Hygienic Chemistry, Division of Food Science and Biotechnology, Department of Bioscience and Biotechnology, Graduate School of Bioresource and Bioenvironmental Sciences, Kyushu University

\section{TSUJI, Sachiko}

College of Food Science and Engineering, Jilin University | Laboratory of Food Hygienic Chemistry, Division of Food Science and Biotechnology, Department of Bioscience and Biotechnology, Graduate School of Bioresource and Bioenvironmental Sciences, Kyushu University

\section{KITAOKA, Hayato}

Laboratory of Food Hygienic Chemistry, Division of Food Science and Biotechnology, Department of Bioscience and Biotechnology, Graduate School of Bioresource and Bioenvironmental Sciences, Kyushu University | College of Food Science and Engineering, Jilin University

\section{TAMAI, Mi tsuru}

Laboratory of Food Hygienic Chemistry, Division of Food Science and Biotechnology, Department of Bioscience and Biotechnology, Graduate School of Bioresource and Bioenvironmental Sciences, Kyushu University | College of Food Science and Engineering, Jilin University

他

https://doi.org/10.5109/1955401

出版情報：九州大学大学院農学研究院紀要. 63 (2)，pp.319-330，2018-09-01. Faculty of Agriculture, Kyushu University

バージョン：

権利関係 : 


\title{
Preparation and Characterization of Monoclonal Antibodies Suitable for Detection of Foodborne Pathogens by Biosensor
}

\author{
Xiao-guang ZHANG ${ }^{1,2, *}$, Sachiko TSUJI ${ }^{2}$, Hayato KITAOKA ${ }^{2}$, Mitsuru TAMAI ${ }^{2}$, \\ Hiroshi KOBAYASHI ${ }^{3}$, Ken-ichi HONJOH ${ }^{4}$ and Takahisa MIYAMOTO ${ }^{4}$
}

\author{
College of Food Science and Engineering, Jilin University, No.5333 Xi'an Street, Changchun, 130062, P.R.China \\ Laboratory of Food Hygienic Chemistry, Division of Food Science and Biotechnology, \\ Department of Bioscience and Biotechnology, Graduate School of Bioresource and \\ Bioenvironmental Sciences, Kyushu University, Fukuoka, 812-8581, Japan \\ (Received April 17, 2018 and accepted May 8, 2018)
}

\begin{abstract}
Monoclonal antibodies (MAbs) for detection of Escherichia coli O157:H7 (O157:H7), Salmonella Enteritidis (SE) and Listeria monocytogenes (LM) using surface plasmon resonance (SPR) biosensor were prepared and characterized. Indirect enzyme-linked immunosorbent assay (ELISA) and SPR biosensor were used for screening of the hybridoma cells secreting MAbs specific to the pathogens. Based on the reactivity of MAbs against the target pathogens by SPR biosensor, MAbs were selected. For O157:H7, the clones $3-11 \mathrm{~B}-3 \mathrm{~F}-8$ and $3-11 \mathrm{~B}-3 \mathrm{~F}-11$, which culture supernatants reacted strongly with boiled 0157:H7 and sonicated O157:H7 cells were obtained and their culture supernatants were used for purification of anti-O157:H7 MAb. For SE, the clone 1-11G-8, which generated high response to sonicated SE cells and the lowest response to the sonicated mixture cells was obtained and the culture supernatant was used for purification of anti-SE MAb for detection of sonicated SE cells. The clone of 3-5H-3F was found with high reactivity against boiled SE and very low against the other boiled samples and was selected for purification of anti-SE MAb for detection of boiled SE cells. For LM, the clone of 2F6-7 that reacted strongest with boiled LM $4 \mathrm{~b}$ was obtained and the culture supernatant was used for purification of anti-LM $4 \mathrm{~b}$ MAb. The clone of 13H9-2 was found to generate almost greatest response against sonicated LM 1/2a and low response to sonicated L. innocua. Moreover, this MAb reacted strongly with boiled LM $4 \mathrm{~b}$ without cross-reactivity against the other bacteria. This clone was selected for purification of anti-LM MAb for the detection of sonicated LM $1 / 2 \mathrm{a}$ or LM $4 \mathrm{~b}$ cells and boiled LM $4 \mathrm{~b}$ cells. Although MAbs for LM showed cross-reactivity against $L$. innocua, the MAbs obtained after screening by the combined method showed a capacity to detect target pathogens by using SPR biosensor as well as ELISA. These MAbs are useful for detection of pathogens by biosensor and are expected to contribute to the development of rapid detection of the pathogens.
\end{abstract}

Key words: SPR biosensor, ELISA, foodborne pathogen, hybridoma, monoclonal antibody

\section{INTRODUCTION}

Surface plasmon resonance (SPR) biosensors, which allow for real-time and label-free detection, have been applied to the detection of foodborne pathogens by many researchers (Karoonuthaisiri et al., 2014; Meeusen et al. , 2005; Subramanian et al., 2006; Tawil et al., 2012; Wei et al., 2007). Previous studies showed that the lower detection limit for pathogen using a SPR biosensor was not only dependent on the sensitivity of the instrument, but also on the specificity and sensitivity of the antibody applied in the detection (Subramanian et al., 2006; Taylor et al., 2005). Polyclonal antibodies have been used for

\footnotetext{
College of Food Science and Engineering, Jilin University, No.5333 Xi'an Street, Changchun, 130062, P.R.China

Laboratory of Food Hygienic Chemistry, Division of Food Science and Biotechnology, Department of Bioscience and Biotechnology, Graduate School of Bioresource and Bioenvironmental Sciences, Kyushu University, Fukuoka, 8128581, Japan

Department of Food and Health Science, International College of Arts and Science, Fukuoka Women's University, Fukuoka, 813-8529, Japan

${ }^{4}$ Laboratory of Food Hygienic Chemistry, Division of Food Science and Biotechnology, Department of Bioscience and Biotechnology, Faculty of Agriculture, Kyushu University, Fukuoka, 812-8581, Japan

* Corresponding author (E-mail: xiaoguang61@jlu.edu.cn)
}

several decades as detection devices for determining foodborne pathogens (Hochel et al., 2007; Velusamy et al., 2010). Although polyclonal antibodies can be raised quickly and cost effectively, they have some disadvantages such as higher potential for cross reactivity due to the recognition of multiple epitopes and variability among different batches produced in different animals at different times (https://www.pacificimmunology.com/ resources/antibody-introduction/polyclonal-vs-monoclonal-antibodies, Jan. 9, 2018). In contrast, monoclonal antibodies (MAbs) are more useful for specific detection of foodborne pathogens and other molecules than polyclonal antibodies (Velusamy et al., 2010), as they are homogeneous, no variability among different batches, and recognize only one epitope on an antigen (http:// www.abcam.com/protocols/a-comparison-between-polyclonal-and-monoclonal, Jan. 9, 2018).

In this study, hybridoma technology was applied to prepare novel MAbs with high sensitivity and specificity that could be used for detection of foodborne pathogens by using SPR biosensor, as well as other immunological detection methods, such as enzyme-linked immunosorbent assay (ELISA). As cross-reactivity is the most important factor in determining the value of an antibody (Tanaka et al., 2003), the specificities of MAbs were tested with various target pathogen-related representative bacterial strains during the screening of MAbs in 
order to guarantee high specificities of the MAbs against target pathogens.

\section{MATERIALS AND METHODS}

\section{Bacteria and cultivation}

Listeria monocytogenes 1/2b LIS 16 No. 22 (LM 1/2b), L. monocytogenes 4b LIS 9 No. 20 (LM 4b) and the following Escherichia coli strains were obtained from the Fukuoka City Institute for Hygiene and the Environment, Fukuoka, Japan: E. coli O157:H7 No. 28 (O157:H7), E. coli O157:H7 No. 30 (O157:H7 No. 30), E. coli O157 No. 139 (O157 No. 139), E. coli O157 No. 144 (O157 No. 144), E. coli O157 No. 166 (O157 No. 166), E. coli O157:H7 No. 196 (O157:H7 No. 196), E. coli O128:H2 No. 20 (O128:H2), E. coli O26 No. 100 (O26), E. coli O91 No. 104 (O91), E. coli O111 No. 107 (O111), O serogroup untypable $E$. coli No. 110 (OUT No. 110), O serogroup untypable $E$. coli No. 116 (OUT No. 116). L. monocytogenes 1/2a SNU A21 No. 136 (LM 1/2a) was obtained from Seoul National University, Seoul, Korea. Salmonella Enteritidis IFO 3313 (SE), S. Typhimurium IFO 12529 (ST), E. coli IFO 3301 (EC) and Enterobacter aerogenes IFO 13534 (EA) were purchased from the Institute for Fermentation, Osaka, Japan. Klebsiella pneumoniae JCM 1662 (KP) and Bacillus cereus JCM 2152 (BC) were purchased from the Japan Collection of Microorganisms, RIKEN Bioresource Center, Tsukuba, Japan. L. innocua (field isolate), L. ivanovii (ATCC 19119), L. seelingeri (ATCC 35967), L. welshimeri (ATCC 35897) and L. grayi (ATCC 25401) were obtained from Obihiro University of Agriculture and Veterinary Medicine, Obihiro, Japan.

Each of the bacterial strains of O157:H7 No. 30, O157 No. 139, O157 No. 144, O157 No. 166, O157:H7 No. 196, O128:H2, O26, O91, O111, OUT No. 110 and OUT No. 116 was cultured in $5 \mathrm{ml}$ of Brain Heart Infusion broth (BHI; Oxoid Ltd., Basingstoke, Hampshire, England) at $37^{\circ} \mathrm{C}$ for $18 \mathrm{~h}$ with shaking at $130 \mathrm{rpm}$. Each of the other bacterial strains was cultured in $5 \mathrm{ml}$ of Tryptic Soy Broth (TSB; Becton, Dickinson and Company, Sparks, MD, USA) at $37^{\circ} \mathrm{C}$ for $18 \mathrm{~h}$ with shaking at $130 \mathrm{rpm}$. Cultures were used for preparation of MAbs and samples for detection.

\section{Preparation of bacterial cells for production of MAbs}

To harvest each of the bacterial cells, each culture of O157:H7 No. 30, O157 No. 139, O157 No. 144, O157 No. 166, O157:H7 No. 196, SE, and LM 1/2a was centrifuged at $5,800 \times \mathrm{g}$ for $5 \mathrm{~min}$. The cells were resuspended in equal amount of Phosphate Buffered Saline (PBS; $137 \mathrm{mM} \mathrm{NaCl}, 8.10 \mathrm{mM} \mathrm{Na}_{2} \mathrm{HPO}_{4}, 2.68 \mathrm{mM} \mathrm{KCl}, 1.47 \mathrm{mM}$ $\mathrm{KH}_{2} \mathrm{PO}_{4}, \mathrm{pH}$ 7.4) to wash cells. The cells were washed twice with PBS as described above. The cells washed triplicate with PBS were used for preparation of MAbs.

\section{Preparation of MAbs}

Anti-0157:H7 MAbs

The cells from $1 \mathrm{ml}$ of the respective cultures of O157:H7 No. 30, O157 No. 139, O157 No. 144, O157 No.
166, and O157:H7 No. 196 were resuspended in $1 \mathrm{ml}$ of PBS. The bacterial suspensions were boiled for $10 \mathrm{~min}$ and then mixed together. The mixture was used as an immunogen. Six-week old female BALB/c mice were immunized with the immunogen by intradermal injection for five times every two weeks. First immunization was performed with $50 \mu \mathrm{g}$ Freund's complete adjuvant, other immunizations with $50 \mu \mathrm{g}$ Freund's incomplete adjuvant. On the third day after the final immunization, spleen cells were isolated and fused with P3X63Ag8U1 (P3U1) myeloma cells. Hybridomas were cultured at $37^{\circ} \mathrm{C}$ in a humidified atmosphere of $5 \% \mathrm{CO}_{2}$ and $95 \%$ air in RPMI 1640 medium supplemented with $15 \%$ heat-inactivated fetal bovine serum (FBS; Life Technologies Corporation, Carlsbad, CA, USA), $100 \mathrm{mg} / \mathrm{l}$ of kanamycin sulfate (Meiji Seika, Tokyo, Japan), and HAT supplement (Thermo Fisher Scientific Inc., Waltham, MA, USA). Culture supernatants of hybridomas were collected and used for evaluation for antibody production by ELISA and SPR biosensor.

Anti-SE MAbs

The cells from $10 \mathrm{ml}$ of the SE culture were resuspended in $10 \mathrm{ml}$ of PBS. The bacterial suspension was boiled for $10 \mathrm{~min}$, and then diluted in PBS to attain cell concentration of approximately $10^{7} \mathrm{CFU} / \mathrm{ml}$. The heattreated bacterial suspension was used as an immunogen. Six-week old female BALB/c mice were immunized via the peritoneal cavity with the heat-inactivated SE cells for five times every two weeks. On the third day after the final immunization, spleen cells were isolated and fused with P3U1 myeloma cells. Hybridization and culture of hybridomas were performed as the same with O157:H7. Culture supernatants were collected and used for evaluation for antibody production by ELISA and SPR biosensor.

Anti-LM MAbs

The cells harvested from $8 \mathrm{ml}$ of the LM 1/2a culture were resuspended in $2 \mathrm{ml}$ of PBS. The bacterial suspension was boiled for $10 \mathrm{~min}$ and used as an immunogen. Six-week old female BALB/c mice were immunized via the peritoneal cavity with heat-inactivated LM 1/2a cells in Freund's complete adjuvant twice, with an interval of one week. Hybridization and culture of hybridomas were performed as the same with O157:H7. Culture supernatants were collected and used as samples for screening of antibodies by ELISA and SPR biosensor.

\section{Preparation of samples for screening of antibodies by SPR biosensor}

After the cultivation, cells were harvested from $1 \mathrm{ml}$ of each culture of O157:H7, EC, EA, KP, SE, ST, LM 1/2a, LM 1/2b, LM 4b, L. innocua, L. ivanovii, BC, L. seelingeri, L. welshimeri, L. grayi by centrifugation at $5,800 \times \mathrm{g}$ for $5 \mathrm{~min}$. Cells were resuspended in $1 \mathrm{ml}$ of HBS-EP buffer (10 mM HEPES, pH 7.4, $150 \mathrm{mM} \mathrm{NaCl}$, $3 \mathrm{mM}$ EDTA, $0.005 \%(\mathrm{v} / \mathrm{v})$ surfactant P20), centrifuged at $5,800 \times \mathrm{g}$ for $5 \mathrm{~min}$, and the cells were resuspended in $1 \mathrm{ml}$ of HBS-EP buffer. The bacterial suspensions were used for following sample preparation. Samples for screening of anti-O157:H7 MAbs 
Each bacterial suspension of O157:H7 and EC was 100-fold diluted with HBS-EP buffer and $10 \mathrm{ml}$ of the 100-fold dilutions with bacterial cells at approximately $10^{7} \mathrm{CFU} / \mathrm{ml}$ were boiled for $10 \mathrm{~min}$ or disrupted thoroughly by sonication using a TOMY Ultrasonic Disruptor UD-201 (TOMY SEIKO CO., LTD, Tokyo, Japan) at $50 \mathrm{~W}$. Each bacterial suspension of EA, KP, SE, LM 1/2a and BC were 5-fold diluted with HBS-EP buffer. One ml of each 5-fold dilution was mixed with $5 \mathrm{ml}$ of HBS-EP buffer. The mixture containing bacterial cells at approximately $10^{8} \mathrm{CFU} / \mathrm{ml}$ was boiled or sonicated as described above.

Samples for screening of anti-SE MAbs

Each bacterial suspension of SE and ST was 100fold diluted with HBS-EP buffer and $10 \mathrm{ml}$ of the 100 fold dilutions with bacterial cells at approximately $10^{7}$ $\mathrm{CFU} / \mathrm{ml}$ were boiled for $10 \mathrm{~min}$ or sonicated as above. One ml of each bacterial suspension of EC, EA, KP, and $\mathrm{BC}$ was mixed with $6 \mathrm{ml}$ of HBS-EP buffer. The mixture with each bacterium at approximately $10^{8} \mathrm{CFU} / \mathrm{ml}$, designated mixture-1, was boiled for $10 \mathrm{~min}$ or sonicated. Each bacterial suspension of O157:H7, LM 1/2a, EC, EA, $\mathrm{KP}$, and BC was 5-fold diluted with HBS-EP buffer. One $\mathrm{ml}$ of each 5-fold dilution was mixed with $4 \mathrm{ml}$ of HBS-EP buffer. The mixture containing bacterial cells at approximately $10^{8} \mathrm{CFU} / \mathrm{ml}$, designated mixture-2, was boiled for $10 \mathrm{~min}$ or sonicated.

Samples for screening of anti-LM MAbs

Each bacterial suspension of LM 1/2a, LM 1/2b, LM 4b, L. innocua, L. seelingeri, L. welshimeri, L. grayi and $L$. ivanovii was 10-fold diluted with HBS-EP buffer and the 10-fold dilutions with bacterial cells at approximately $10^{8} \mathrm{CFU} / \mathrm{ml}$ were boiled for $10 \mathrm{~min}$ or sonicated. Each bacterial suspension of O157:H7, EC, EA, KP, SE, and BC was 5-fold diluted with HBS-EP buffer. One ml of each 5-fold dilution was mixed with $4 \mathrm{ml}$ of HBS-EP buffer. The mixture containing bacterial cells at approximately $10^{8} \mathrm{CFU} / \mathrm{ml}$ was boiled for $10 \mathrm{~min}$ or sonicated.

All the samples prepared for screening of antibodies by SPR biosensor were stored at $-20^{\circ} \mathrm{C}$ until use.

\section{Screening of MAbs using indirect ELISA}

Activity of MAbs was examined using an indirect ELISA method. The wells of a Nunc Maxisorp ${ }^{\mathrm{TM}}$ plate were coated with $40 \mu \mathrm{l}$ aliquots of respective target antigen (the immunogen used in immunization for raising anti-O157:H7 MAbs and anti-SE MAbs, 100-fold dilution of the immunogen in PBS for raising anti-LM MAbs) or where a mixed bacterial suspension of non-0157 pathogenic E. coli strains was used, i.e., O128:H2, O26, O91, O111, OUT No. 110 and OUT No. 116 in PBS. The plates were incubated overnight at $4^{\circ} \mathrm{C}$ and then blocked with a $1 \%(w / v)$ solution of block ace (Dainippon Sumitomo Pharma Co., Ltd., Tokyo, Japan) in PBS. A $50 \mu$ l sample of culture supernatant of hybridoma was added to the wells of the plate. Plates were incubated at $37^{\circ} \mathrm{C}$ for $1.5 \mathrm{~h}$ on a rocking platform. The wells were washed three times with PBS, and $50 \mu \mathrm{l}$ of secondary antibody [horseradish peroxidase-labeled goat anti-mouse immunoglobulin (IgG, IgM, and IgA) antibody for anti-O157:H7 MAbs and anti-SE MAbs screening; alkaline phosphataselabeled goat anti-mouse immunoglobulin (IgG, IgM, and IgA) antibody for anti-LM MAbs screening, Merck, Darmstadt, Germany] diluted in PBS was added. After a $1.5 \mathrm{~h}$-incubation at $37^{\circ} \mathrm{C}$, the wells were washed five times with PBS, and $50 \mu \mathrm{l}$ of substrate was added to each well. After incubation in the dark at $37^{\circ} \mathrm{C}$ for $1 \mathrm{~h}$, absorbance was determined at the most appropriate wavelength, $490 \mathrm{~nm}$ for screening anti-O157:H7 MAbs \& anti-SE MAbs and $510 \mathrm{~nm}$ for anti-LM MAbs, using a microplate reader (Model 680; Bio-Rad, Tokyo, Japan).

\section{SPR instrumentation}

Analysis was carried out on a Biacore X instrument (GE Healthcare Bio-Sciences AB, Uppsala, Sweden) using sensor chip CM3 (GE Healthcare Bio-Sciences AB). Biacore $\mathrm{X}$ was equipped with two flow channels: flow channel 1 for reference and flow channel 2 for detection.

\section{Immobilization of anti-mouse IgG antibody on sensor chip}

Anti-mouse IgG antibody (GE Healthcare BioSciences AB), which binds to all IgG subclasses, IgA, and IgM antibodies from mouse, was used as a capture antibody for the MAbs. The amine-coupling method was used for antibody immobilization (Löfås and Johnsson, 1990). Anti-mouse IgG antibody was immobilized on flow channel 2 by injecting the antibody at $50 \mu \mathrm{g} / \mathrm{ml}$ in $10 \mathrm{mM}$ acetate buffer ( $\mathrm{pH} 5.0$ ) at a flow rate of $15 \mu \mathrm{l} / \mathrm{min}$ for $7 \mathrm{~min}$. Flow channel 1 was left blank to serve as a reference channel. After antibody immobilization, the surfaces of both flow channels were blocked by injecting $1.0 \mathrm{M}$ ethanolamine- $\mathrm{HCl}$ ( $\mathrm{pH}$ 8.5) for $7 \mathrm{~min}$ to minimize non-specific adsorption (Rich and Myszka, 2001).

\section{Screening of MAbs using SPR biosensor}

The sensor chip CM3 with anti-mouse IgG antibody was docked into the Biacore X instrument. HBS-EP buffer was used as a running buffer and run at a flow rate of $15 \mu \mathrm{l} / \mathrm{min}$ and $25^{\circ} \mathrm{C}$. Culture supernatant of hybridoma was diluted appropriately with HBS-EP buffer and then injected for $6 \mathrm{~min}$ at a flow rate of $15 \mu \mathrm{l} / \mathrm{min}$. MAb in the culture supernatant was captured by anti-mouse IgG antibody immobilized on sensor chip CM3 as the culture supernatant passed over the sensor chip surface. After immobilization of MAb, HBS-EP buffer was injected for 5 min to establish a baseline. Then the corresponding bacterial samples were injected one by one for 5 min for antigen-antibody binding. Signal change for each sample was obtained by subtracting the signal recorded at $30 \mathrm{~s}$ before the start of the sample injection from the signal recorded at $60 \mathrm{~s}$ after the end of the sample injection. After measurement of all the samples, regeneration solution (10 mM glycine-HCl, pH 1.7) was injected for 3 min to dissociate antigen and MAb from anti-mouse IgG antibody. After regeneration, sensor chip surfaces were equilibrated with running buffer (HBS-EP buffer). This sensor chip immobilized with anti-mouse IgG antibody was then used to evaluate another culture supernatant of hybridoma. 


\section{RESULTS}

\section{Screening and characterization of anti-0157:H7 MAbs}

A total of 621 hybridoma cell lines were obtained after the cell fusion. The cell lines producing MAbs specific to O157:H7 were screened by ELISA. The reaction between the culture supernatants of the hybridomas and target antigen (O157 antigen), i.e., the mixture of bacterial suspension of boiled O157:H7 No. 30, O157 No. 139, O157 No. 144, O157 No. 166, and O157:H7 No. 196 in PBS that was used as the immunogen, was tested. After this preliminary screening, 43 cell lines were found to secrete MAbs specific to O157:H7 (Table 1). Then these selected cell lines were screened by using SPR biosensor. Cells of EC, O157:H7, and the mixture including EA, KP, SE, LM 1/2a and BC, were boiled or sonicated before applying to SPR biosensor. As shown in Table 2, the culture supernatants form 4 cell lines, $1-1 \mathrm{~A}, 3-11 \mathrm{~B}, 6-4 \mathrm{G}$, and $6-7 \mathrm{H}$, reacted strongly with boiled $\mathrm{O} 157: \mathrm{H} 7$, without cross-reactivity against boiled EC or boiled mixture sample. Culture supernatants from other cell lines showed relative high response to boiled O157:H7 (2-10D and 5-12A) or sonicated $\mathrm{O} 157: \mathrm{H7}$ (4-8A, 5-12F, 6-3H, and $7-4 \mathrm{~A}$ ) although they showed cross-reactivity against EC or the mixture samples. These 10 cell lines were selected for subsequent cloning. Twenty-nine individual clones were obtained after cloning and re-screened by ELISA. The reactivity of the culture supernatants of the hybridomas with target antigen (O157 antigen) as well as nontarget antigen (non-O157 antigen, i.e., the mixture of bacterial suspension of boiled O128:H2, O26, O91, O111, OUT No. 110 and OUT No. 116 in PBS) was investigated. Reactivity of the culture supernatants from 7 clones, 3-11B-3F-2, 3-11B-3F-3, 3-11B-3F-7, 3-11B-3F-8, $3-11 \mathrm{~B}-3 \mathrm{~F}-9, \quad 3-11 \mathrm{~B}-3 \mathrm{~F}-11$, and $6-7 \mathrm{H}-1$, was high enough against $\mathrm{O} 157$ antigen, but very low against the
Table 1. Reactivity of culture supernatants of hybridoma cell lines raised against $\mathrm{O} 157$ determined by ELISA

\begin{tabular}{|c|c|c|c|}
\hline Cell line & $\begin{array}{c}\text { Reactivity } \\
\left(\mathrm{A}_{490}\right)\end{array}$ & Cell line & $\begin{array}{c}\text { Reactivity } \\
\left(\mathrm{A}_{490}\right)\end{array}$ \\
\hline $1-1 \mathrm{~A}$ & 2.956 & $5-2 \mathrm{D}$ & 0.261 \\
\hline $2-3 B$ & 0.214 & $5-8 \mathrm{D}$ & 2.714 \\
\hline $2-6 \mathrm{~A}$ & 0.331 & 5-10D & 0.286 \\
\hline $2-10 \mathrm{~A}$ & 2.978 & $5-12 \mathrm{~A}$ & 2.845 \\
\hline $2-10 \mathrm{D}$ & 1.833 & $5-12 \mathrm{~F}$ & 0.337 \\
\hline $3-1 \mathrm{D}$ & 0.225 & $6-1 \mathrm{~A}$ & 0.326 \\
\hline $3-3 B$ & 0.220 & $6-1 B$ & 0.276 \\
\hline $3-3 D$ & 2.869 & $6-1 \mathrm{H}$ & 2.376 \\
\hline $3-3 \mathrm{~F}$ & 1.077 & $6-3 \mathrm{H}$ & 2.514 \\
\hline $3-11 B$ & 2.949 & $6-4 \mathrm{G}$ & 2.891 \\
\hline $3-12 \mathrm{~A}$ & 2.611 & $6-5 \mathrm{D}$ & 2.910 \\
\hline $4-5 \mathrm{D}$ & 0.503 & $6-7 \mathrm{H}$ & 2.948 \\
\hline $4-6 \mathrm{~A}$ & 2.923 & $6-10 \mathrm{G}$ & 0.434 \\
\hline $4-7 \mathrm{D}$ & 0.256 & $6-12 \mathrm{~B}$ & 0.394 \\
\hline $4-8 \mathrm{~A}$ & 0.497 & $7-1 \mathrm{D}$ & 0.274 \\
\hline 4-9D & 2.998 & $7-1 \mathrm{G}$ & 0.255 \\
\hline 4-11D & 2.406 & $7-2 \mathrm{~A}$ & 2.860 \\
\hline $4-11 \mathrm{~F}$ & 0.382 & $7-3 B$ & 0.273 \\
\hline $4-12 \mathrm{~A}$ & 1.119 & $7-4 \mathrm{~A}$ & 2.891 \\
\hline $4-12 B$ & 1.325 & $7-5 \mathrm{~A}$ & 0.935 \\
\hline $4-12 \mathrm{D}$ & 0.375 & $\mathrm{NC}^{*}$ & 0.069 \\
\hline $4-12 \mathrm{H}$ & 0.967 & $\mathrm{PC}^{* *}$ & 2.947 \\
\hline $5-1 \mathrm{D}$ & 0.271 & & \\
\hline
\end{tabular}

*NC: the blank control with the coating buffer only.

**PC: the positive control with 1000-fold diluted antiserum of immunized mouse.

Table 2. Reactivity of culture supernatants of hybridoma cell lines raised against O157 against various bacteria by SPR biosensor

\begin{tabular}{|c|c|c|c|c|c|c|c|c|}
\hline \multirow{3}{*}{$\begin{array}{l}\text { Cell } \\
\text { line }\end{array}$} & \multicolumn{8}{|c|}{ Signal change (RU) } \\
\hline & \multirow{2}{*}{$\begin{array}{l}\text { Immobilization } \\
\text { of antibody }\end{array}$} & \multirow{2}{*}{$\begin{array}{l}\mathrm{HBS} \\
-\mathrm{EP}\end{array}$} & \multicolumn{3}{|c|}{ Boiled samples } & \multicolumn{3}{|c|}{ Sonicated samples } \\
\hline & & & $\mathrm{EC}$ & O157:H7 & Mixture* & $\mathrm{EC}$ & O157:H7 & Mixture* \\
\hline $1-1 \mathrm{~A}$ & 631.6 & -11.0 & -6.7 & 9.5 & -6.5 & -3.3 & 12.4 & 22.0 \\
\hline $2-3 \mathrm{~B}$ & 511.1 & -8.6 & -5.5 & -2.6 & 0.4 & -2.0 & -1.8 & 12.9 \\
\hline $2-6 \mathrm{~A}$ & 439.6 & -7.0 & -5.1 & -2.1 & -2.3 & -1.3 & 0.0 & 12.8 \\
\hline $2-10 \mathrm{~A}$ & 267.1 & -3.4 & -3.2 & -1.7 & 1.7 & -1.6 & -0.5 & 12.6 \\
\hline $2-10 \mathrm{D}$ & 180.3 & -5.0 & 16.5 & 11.8 & 18.2 & 20.4 & 1.3 & 61.1 \\
\hline $3-1 \mathrm{D}$ & 620.0 & -6.0 & -3.8 & -1.6 & -0.5 & -0.2 & 1.8 & 13.4 \\
\hline $3-3 \mathrm{~B}$ & 182.4 & -2.3 & -2.5 & -1.0 & -0.2 & 1.7 & 1.3 & 12.1 \\
\hline $3-3 \mathrm{D}$ & 371.8 & -7.0 & -4.6 & -1.7 & -1.1 & -2.0 & -0.9 & 9.6 \\
\hline $3-3 \mathrm{~F}$ & 244.2 & -6.7 & -6.6 & -2.1 & -2.9 & -3.9 & 0.2 & 15.8 \\
\hline $3-11 \mathrm{~B}$ & 444.1 & -2.3 & -2.3 & 39.0 & -0.9 & 0.9 & 102.5 & 13.5 \\
\hline $3-12 \mathrm{~A}$ & 462.8 & -2.1 & -2.3 & -0.1 & 1.3 & 0.8 & 3.5 & 16.5 \\
\hline $4-5 \mathrm{D}$ & 151.7 & -7.4 & -6.2 & -3.3 & -3.3 & -1.4 & -0.9 & 10.6 \\
\hline $4-6 \mathrm{~A}$ & 721.4 & -10.8 & -2.3 & -2.2 & 9.0 & 8.3 & 7.0 & 70.0 \\
\hline
\end{tabular}


Table 2. (Continued).

\begin{tabular}{|c|c|c|c|c|c|c|c|c|}
\hline \multirow{3}{*}{$\begin{array}{l}\text { Cell } \\
\text { line }\end{array}$} & \multicolumn{8}{|c|}{ Signal change (RU) } \\
\hline & \multirow{2}{*}{$\begin{array}{l}\text { Immobilization } \\
\text { of antibody }\end{array}$} & \multirow{2}{*}{$\begin{array}{l}\text { HBS } \\
-\mathrm{EP}\end{array}$} & \multicolumn{3}{|c|}{ Boiled samples } & \multicolumn{3}{|c|}{ Sonicated samples } \\
\hline & & & $\mathrm{EC}$ & $\mathrm{O} 157: \mathrm{H7}$ & Mixture* & $\mathrm{EC}$ & O157:H7 & Mixture* \\
\hline $4-7 \mathrm{D}$ & 406.1 & -5.7 & -5.4 & -3.4 & -1.7 & -0.1 & 1.2 & 22.4 \\
\hline $4-8 \mathrm{~A}$ & 511.0 & -3.1 & -3.5 & -2.0 & -1.1 & 15.0 & 26.3 & 21.0 \\
\hline $4-9 \mathrm{D}$ & 631.4 & -5.7 & 11.1 & 0.7 & 35.5 & 45.7 & 4.3 & 29.9 \\
\hline $4-11 \mathrm{D}$ & 413.3 & -13.1 & -3.5 & 0.4 & -1.4 & 5.1 & 7.5 & 38.1 \\
\hline $4-11 \mathrm{~F}$ & 155.2 & -4.1 & -2.1 & -0.6 & 1.1 & 2.3 & 4.3 & 34.7 \\
\hline $4-12 \mathrm{~A}$ & 198.7 & -5.2 & -4.8 & -0.3 & -0.2 & 2.5 & 4.9 & 33.3 \\
\hline $4-12 B$ & 495.7 & -9.8 & -7.4 & -2.6 & -3.0 & 0.6 & 3.4 & 29.4 \\
\hline $4-12 \mathrm{D}$ & 294.4 & -5.7 & -5.2 & 0.6 & -1.0 & 2.9 & 3.1 & 36.4 \\
\hline $4-12 \mathrm{H}$ & 321.7 & -7.8 & -7.0 & -1.0 & -2.9 & 1.6 & 1.7 & 33.5 \\
\hline $5-1 \mathrm{D}$ & 177.2 & -5.6 & -5.4 & -0.8 & -2.5 & 1.9 & 2.8 & 31.5 \\
\hline $5-2 \mathrm{D}$ & 160.0 & -5.1 & -3.3 & -1.5 & -2.5 & 0.3 & 2.0 & 30.0 \\
\hline $5-8 \mathrm{D}$ & 791.1 & -13.1 & -9.4 & -6.3 & -6.3 & 2.1 & 5.0 & 37.0 \\
\hline 5-10D & 145.3 & -3.6 & -2.9 & -1.4 & 0.1 & 1.6 & 4.3 & 36.8 \\
\hline 5-12A & 701.2 & -8.0 & 8.3 & 7.8 & 10.2 & 22.2 & 3.6 & 66.0 \\
\hline $5-12 \mathrm{~F}$ & 335.7 & -10.8 & -8.3 & -4.2 & -4.9 & 14.2 & 22.2 & 60.8 \\
\hline $6-1 \mathrm{~A}$ & 224.9 & -6.9 & -6.6 & -3.5 & 0.5 & 0.5 & 7.6 & 49.4 \\
\hline $6-1 B$ & 194.8 & -9.8 & -7.9 & -3.6 & -2.9 & 1.7 & 5.4 & 44.4 \\
\hline $6-1 \mathrm{H}$ & 299.8 & -7.2 & -5.6 & -2.7 & -1.9 & 0.8 & 4.9 & 38.1 \\
\hline $6-3 \mathrm{H}$ & 303.0 & -9.2 & 2.0 & -0.9 & 8.6 & 16.8 & 10.6 & 83.4 \\
\hline $6-4 \mathrm{G}$ & 99.1 & -3.1 & -3.7 & 6.5 & -0.3 & 4.6 & 20.4 & 53.7 \\
\hline $6-5 \mathrm{D}$ & 276.7 & -4.4 & -4.7 & -2.7 & -0.6 & 3.5 & 7.6 & 57.2 \\
\hline $6-7 \mathrm{H}$ & 194.0 & -3.3 & -3.3 & 20.0 & -1.1 & 3.0 & 53.0 & 43.2 \\
\hline $6-10 \mathrm{G}$ & 138.4 & -3.7 & -1.7 & 0.6 & 3.0 & 4.1 & 6.5 & 56.8 \\
\hline $6-12 B$ & 94.1 & -3.4 & -3.6 & -2.1 & -1.5 & 3.6 & 5.6 & 55.4 \\
\hline $7-1 \mathrm{D}$ & 399.3 & -5.7 & -4.6 & -2.2 & -1.7 & 2.1 & 4.6 & 48.3 \\
\hline $7-1 \mathrm{G}$ & 187.0 & -7.0 & -3.9 & -2.4 & -0.5 & 2.5 & 6.3 & 46.9 \\
\hline $7-2 \mathrm{~A}$ & 294.3 & -11.1 & -7.1 & -2.9 & -3.8 & 3.2 & 7.2 & 65.4 \\
\hline $7-3 \mathrm{~B}$ & 96.1 & -3.9 & -3.7 & -1.1 & 0.0 & 3.0 & 6.8 & 51.0 \\
\hline $7-4 \mathrm{~A}$ & 353.3 & -7.2 & -5.3 & -0.6 & 2.7 & 5.0 & 10.3 & 54.2 \\
\hline $7-5 \mathrm{~A}$ & 202.6 & -6.9 & -4.0 & -1.6 & -0.9 & 3.2 & 7.8 & 40.4 \\
\hline
\end{tabular}

*Mixture: the mixture of bacterial suspension of EA, KP, SE, LM 1/2a and BC in HBS-EP.

Cell concentrations of O157:H7 and EC were approximately $10^{7} \mathrm{CFU} / \mathrm{ml}$, mixture was approximately $10^{8} \mathrm{CFU} / \mathrm{ml}$.

non-0157 antigen (Table 3). These culture supernatants were re-screened by using SPR biosensor. The culture supernatants from clones $3-11 \mathrm{~B}-3 \mathrm{~F}-8$ and $3-11 \mathrm{~B}-$ $3 \mathrm{~F}-11$ strongly reacted with boiled $\mathrm{O} 157: \mathrm{H7}$ and sonicated O157:H7 samples, without cross-reaction against the other samples (Table 4). These 2 clones were selected for purification of anti-O157:H7 MAb.

\section{Screening and characterization of anti-SE MAbs}

A total of 432 hybridoma cell lines were obtained after the cell fusion. The reaction between the culture supernatants of the hybridomas and the target antigen of boiled SE was tested. After the preliminary screening, 28 cell lines were found to secrete MAbs specific to boiled SE (Table 5). Then these selected cell lines were screened by using SPR biosensor. Cells of SE, ST, and mixture-1 including EC, EA, KP, and BC, were boiled or sonicated before applying to SPR biosensor. As shown in Table 6 , culture supernatants from 10 cell lines (1-4A, 1-4B, 1-11G, 2-7H, 2-8H, 3-5H, 3-7A, 3-8F, 3-10F, and 5-6C) strongly reacted with boiled SE or sonicated SE with low reactivity to the other samples (Table 6). They were selected for subsequent cloning. Twenty-four individual clones were obtained after the cloning and rescreened by using SPR biosensor. Table 7 shows the reactivity of the culture supernatants from the selected clones against SE and the other bacterial samples. Several culture supernatants from the selected clones reacted strongly with boiled SE. In particular, clone of $3-5 \mathrm{H}-3 \mathrm{~F}$ was found to produce MAb with high reactivity 
Table 3. Reactivity of the selected culture supernatants of hybridomas raised against O157 against O157 and non-O157 by ELISA

\begin{tabular}{|c|c|c|c|c|c|}
\hline \multirow{2}{*}{ Clone } & \multicolumn{2}{|c|}{ Reactivity $\left(\mathrm{A}_{490}\right)$} & \multirow{2}{*}{ Clone } & \multicolumn{2}{|c|}{ Reactivity $\left(\mathrm{A}_{490}\right)$} \\
\hline & O157 & Non-O157 \#\# & & $\mathrm{O} 157^{\#}$ & Non-O157 \#\# \\
\hline $3-11 \mathrm{~B}-3 \mathrm{~F}-2$ & 2.889 & 0.114 & $5-12 \mathrm{~A}-4$ & 2.929 & 2.932 \\
\hline $3-11 \mathrm{~B}-3 \mathrm{~F}-3$ & 2.981 & 0.100 & $5-12 \mathrm{~A}-5$ & 2.999 & 3.026 \\
\hline $3-11 \mathrm{~B}-3 \mathrm{~F}-7$ & 2.865 & 0.111 & $5-12 \mathrm{~F}-1$ & 0.892 & 1.009 \\
\hline $3-11 \mathrm{~B}-3 \mathrm{~F}-8$ & 2.992 & 0.108 & $5-12 \mathrm{~F}-4$ & 0.865 & 0.969 \\
\hline $3-11 \mathrm{~B}-3 \mathrm{~F}-9$ & 2.881 & 0.111 & $5-12 \mathrm{~F}-5$ & 0.812 & 0.913 \\
\hline $3-11 \mathrm{~B}-3 \mathrm{~F}-11$ & 2.927 & 0.132 & $5-12 \mathrm{~F}-9$ & 0.735 & 0.826 \\
\hline $4-8 \mathrm{~A}-1$ & 0.899 & 1.105 & $5-12 \mathrm{~F}-11$ & 0.683 & 0.755 \\
\hline $4-8 \mathrm{~A}-2$ & 0.696 & 1.000 & $5-12 F-12$ & 0.761 & 0.810 \\
\hline $4-8 \mathrm{~A}-3$ & 0.999 & 1.201 & $5-12 \mathrm{~F}-14$ & 0.977 & 1.107 \\
\hline $4-8 \mathrm{~A}-4$ & 0.988 & 1.182 & $6-3 \mathrm{H}-1$ & 0.778 & 1.236 \\
\hline $4-8 \mathrm{~A}-5$ & 1.016 & 1.151 & $6-3 \mathrm{H}-2$ & 0.749 & 1.190 \\
\hline $4-8 \mathrm{~A}-6$ & 1.021 & 1.207 & $6-3 \mathrm{H}-3$ & 1.381 & 1.296 \\
\hline $4-8 \mathrm{~A}-7$ & 0.967 & 1.094 & $6-7 \mathrm{H}-1$ & 2.911 & 0.099 \\
\hline $5-12 \mathrm{~A}-1$ & 2.911 & 2.930 & $\mathrm{NC}^{*}$ & 0.111 & 0.100 \\
\hline $5-12 \mathrm{~A}-2$ & 2.909 & 2.924 & $\mathrm{PC}^{* *}$ & 2.922 & 2.918 \\
\hline $5-12 \mathrm{~A}-3$ & 2.899 & 2.945 & & & \\
\hline
\end{tabular}

O157" : the mixture of bacterial suspension of boiled O157:H7 No. 30, O157 No. 139, O157 No. 144, O157 No. 166, and O157:H7 No. 196 in PBS that was used as immunogen in the immunization.

Non-O157 : the mixture of bacterial suspension of boiled O128:H2, O26, O91, O111, OUT No. 110 and OUT No. 116 in PBS.

*NC: the blank control with the coating buffer only.

**PC: the positive control with 1000-fold diluted antiserum of immunized mouse.

Table 4. Reactivity of the selected culture supernatants of hybridomas raised against O157 against various bacteria by SPR biosensor

\begin{tabular}{|c|c|c|c|c|c|c|c|c|}
\hline \multirow{3}{*}{ Clone } & \multicolumn{8}{|c|}{ Signal change (RU) } \\
\hline & \multirow{2}{*}{$\begin{array}{l}\text { Immobilization } \\
\text { of antibody }\end{array}$} & \multirow{2}{*}{$\begin{array}{l}\text { HBS } \\
-\mathrm{EP}\end{array}$} & \multicolumn{3}{|c|}{ Boiled samples } & \multicolumn{3}{|c|}{ Sonicated samples } \\
\hline & & & $\mathrm{EC}$ & O157:H7 & Mixture* & $\mathrm{EC}$ & O157:H7 & Mixture* \\
\hline $3-11 \mathrm{~B}-3 \mathrm{~F}-2$ & 569.3 & -9.4 & -4.3 & 64.7 & -5.8 & -2.8 & 77.8 & 4.6 \\
\hline $3-11 \mathrm{~B}-3 \mathrm{~F}-3$ & 509.5 & -13.1 & -14.1 & 49.4 & -6.2 & -4.9 & 69.8 & 4.8 \\
\hline $3-11 \mathrm{~B}-3 \mathrm{~F}-7$ & 341.3 & -1.6 & -1.8 & 44.1 & -2.0 & -3.1 & 50.2 & -0.9 \\
\hline $3-11 B-3 F-8$ & 770.9 & -1.6 & -1.3 & 83.7 & -5.6 & -2.5 & 111.0 & -1.2 \\
\hline 3-11B-3F-9 & 459.4 & -23.1 & -14.7 & 53.0 & -8.9 & -8.3 & 71.0 & 0.5 \\
\hline $3-11 \mathrm{~B}-3 \mathrm{~F}-11$ & 519.3 & -4.5 & -0.4 & 72.6 & -6.1 & -1.9 & 84.1 & -1.8 \\
\hline $6-7 \mathrm{H}-1$ & 361.8 & -5.1 & -3.3 & 41.2 & -2.6 & -1.3 & 48.7 & 13.6 \\
\hline
\end{tabular}

*Mixture: the mixture of bacterial suspension of EA, KP, SE, LM 1/2a and BC in HBS-EP.

Cell concentrations of O157:H7 and EC were approximately $10^{7} \mathrm{CFU} / \mathrm{ml}$, mixture was approximately $10^{8} \mathrm{CFU} / \mathrm{ml}$.

against boiled SE and very low against the other boiled samples. This clone was selected for detection of boiled $\mathrm{SE}$ and MAb was purified from the culture supernatant. All tested culture supernatants from the clones reacted positively with both sonicated SE and sonicated mixture-2 including O157:H7, LM 1/2a, EC, EA, KP, and BC. Since the reactivity of the culture supernatants from clone $1-11 \mathrm{G}-8$ to the sonicated mixture-2 sample was the lowest among them, MAb to detect sonicated SE was purified from the culture supernatant of the clone.

\section{Screening and characterization of anti-LM MAbs}

A total of 120 hybridoma cell lines were obtained after the cell fusion. The cell lines producing MAbs specific to boiled LM 1/2a were screened. After this preliminary screening, 24 cell lines were found to secrete MAbs specific to boiled LM 1/2a (Table 8). These selected cell lines were screened by using SPR biosensor. Cells of LM 1/2a, LM 1/2b, LM 4b, L. innocua, and mixture including O157:H7, EC, EA, KP, SE, and BC, were boiled or sonicated before applying to SPR biosen- 
Table 5. Reactivity of culture supernatants of hybridoma cell lines raised against SE determined by ELISA

\begin{tabular}{cccc}
\hline Cell line & $\begin{array}{c}\text { Reactivity } \\
\left(\mathrm{A}_{490}\right)\end{array}$ & Cell line & $\begin{array}{c}\text { Reactivity } \\
\left(\mathrm{A}_{490}\right)\end{array}$ \\
\hline $1-4 \mathrm{~A}$ & 2.977 & $3-8 \mathrm{~F}$ & 3.000 \\
$1-4 \mathrm{~B}$ & 2.959 & $3-10 \mathrm{~F}$ & 2.983 \\
$1-5 \mathrm{~F}$ & 2.934 & $4-3 \mathrm{G}$ & 2.925 \\
$1-7 \mathrm{D}$ & 3.000 & $4-4 \mathrm{~B}$ & 3.000 \\
$1-8 \mathrm{~A}$ & 2.968 & $4-5 \mathrm{~A}$ & 2.969 \\
$1-8 \mathrm{~B}$ & 2.974 & $4-6 \mathrm{~B}$ & 3.000 \\
$1-11 \mathrm{G}$ & 2.937 & $4-8 \mathrm{~A}$ & 2.907 \\
$2-7 \mathrm{H}$ & 3.000 & $4-9 \mathrm{D}$ & 3.000 \\
$2-8 \mathrm{H}$ & 2.999 & $4-10 \mathrm{H}$ & 2.975 \\
$3-2 \mathrm{E}$ & 2.910 & $4-11 \mathrm{C}$ & 2.972 \\
$3-2 \mathrm{H}$ & 2.953 & $5-2 \mathrm{D}$ & 2.963 \\
$3-5 \mathrm{E}$ & 2.936 & $5-6 \mathrm{C}$ & 2.956 \\
$3-5 \mathrm{H}$ & 2.962 & $5-6 \mathrm{D}$ & 3.000 \\
$3-7 \mathrm{~A}$ & 2.989 & NC** & 0.166 \\
$3-7 \mathrm{~B}$ & 3.000 & $\mathrm{PC} * *$ & 3.000 \\
\hline
\end{tabular}

*NC: the blank control with the coating buffer only.

**PC: the positive control with 1000-fold diluted antiserum of immunized mouse. sor. As shown in Table 9, almost all culture supernatants from the selected cell lines showed no reactivity against boiled LM 1/2a, the target antigen, while the culture supernatants from 4 cell lines (1F10, 2A6, 2F6, and 13H9) showed high reactivity only against boiled LM 4b. Against sonicated LM 1/2a, the culture supernatants from 5 cell lines (1F2, 1F10, 2A7, 2F6, and 13H9), especially $2 \mathrm{~F} 6$ and $13 \mathrm{H} 9$, showed high reactivity.

Although all the culture supernatants of 5 cell lines showed cross-reactivity against sonicated non-pathogenic Listeria strains, i.e., L. seelingeri, L. welshimeri, $L$. grayi and $L$. ivanovii, the culture supernatants of 2 cell lines (2F6 and 13H9) showed lower cross-reactivity against the sonicated mixture sample compared with those of the other 3 cell lines (Table 10). Moreover, the culture supernatants of the 2 cell lines strongly reacted with boiled LM 4b (Table 9). Based on these results, cell lines of $2 \mathrm{~F} 6$ and $13 \mathrm{H} 9$ were selected for further cloning. Table 11 shows the reactivity of the culture supernatants of the 31 clones determined by SPR biosensor. Clone of 2F6-7 was found to produce MAb with high reactivity against boiled LM $4 \mathrm{~b}$ and thus was selected for detection of boiled LM 4b and MAb was purified from the culture supernatant. The culture supernatants of the other clones derived from the cell line $2 \mathrm{~F} 6$ had almost no reactivity against boiled or sonicated LM, thus cross-reactiv-

Table 6. Reactivity of culture supernatants of hybridoma cell lines raised against SE against various bacteria by SPR biosensor

\begin{tabular}{|c|c|c|c|c|c|c|c|c|}
\hline \multirow{3}{*}{$\begin{array}{l}\text { Cell } \\
\text { line }\end{array}$} & \multicolumn{8}{|c|}{ Signal change (RU) } \\
\hline & \multirow{2}{*}{$\begin{array}{l}\text { Immobilization } \\
\text { of antibody }\end{array}$} & \multirow{2}{*}{ HBS-EP } & \multicolumn{3}{|c|}{ Boiled samples } & \multicolumn{3}{|c|}{ Sonicated samples } \\
\hline & & & $\mathrm{SE}$ & $\mathrm{ST}$ & Mixture-1* & SE & ST & Mixture-1* \\
\hline $1-4 \mathrm{~A}$ & 177.8 & -5.3 & 20.1 & -0.7 & 92.7 & 23.2 & -0.9 & 58.7 \\
\hline $1-4 \mathrm{~B}$ & 179.5 & -6.1 & 19.6 & -1.0 & 87.7 & 22.0 & -1.2 & 58.0 \\
\hline $1-5 \mathrm{~F}$ & 133.0 & -1.9 & 10.6 & 1.2 & 46.0 & 14.8 & -0.2 & 30.2 \\
\hline $1-7 \mathrm{D}$ & 108.6 & -1.9 & 6.5 & 0.0 & 4.9 & 2.5 & -0.7 & 23.2 \\
\hline $1-8 \mathrm{~A}$ & 108.9 & 0.1 & 0.2 & -0.4 & -0.1 & 1.1 & -0.5 & 2.5 \\
\hline $1-8 \mathrm{~B}$ & 121.3 & -0.8 & 0.9 & 0.1 & -0.6 & 0.6 & -0.8 & 3.5 \\
\hline $1-11 \mathrm{G}$ & 125.0 & -1.4 & 0.7 & -1.6 & -0.3 & 13.1 & 0.0 & 3.6 \\
\hline $2-7 \mathrm{H}$ & 137.9 & -1.3 & -12.6 & -0.9 & 4.3 & 28.1 & -0.9 & 30.0 \\
\hline $2-8 \mathrm{H}$ & 57.5 & -0.1 & 2.6 & 0.7 & 2.2 & 6.3 & -0.6 & 5.5 \\
\hline $3-2 \mathrm{E}$ & 126.6 & -1.0 & -0.1 & -0.4 & -0.9 & 0.5 & -0.5 & 1.6 \\
\hline $3-2 \mathrm{H}$ & 115.3 & -0.8 & 1.1 & 0.3 & -1.7 & 1.2 & 0.3 & 8.2 \\
\hline $3-5 \mathrm{E}$ & 184.6 & -1.2 & 0.5 & 1.2 & -0.5 & 1.2 & -0.1 & 2.8 \\
\hline $3-5 \mathrm{H}$ & 238.3 & -4.7 & 37.2 & 0.7 & 15.7 & 4.3 & -0.8 & 80.3 \\
\hline $3-7 \mathrm{~A}$ & 222.9 & -3.1 & 25.5 & 1.0 & 11.5 & 7.4 & 0.1 & 95.5 \\
\hline $3-7 \mathrm{~B}$ & 162.4 & -2.4 & -0.9 & -0.1 & -2.7 & -0.3 & -1.8 & 0.2 \\
\hline $3-8 \mathrm{~F}$ & 104.8 & -2.4 & 2.2 & -1.2 & -0.7 & 9.3 & -0.7 & -0.9 \\
\hline $3-10 \mathrm{~F}$ & 105.7 & -3.3 & 2.2 & -0.1 & -1.0 & 8.9 & -1.0 & 2.6 \\
\hline $4-3 G$ & 147.7 & -2.9 & -0.5 & -0.8 & -2.6 & 0.1 & -0.4 & 1.6 \\
\hline $4-4 B$ & 139.6 & -2.1 & 0.1 & -0.2 & 1.9 & -1.0 & -0.6 & 35.1 \\
\hline $4-5 \mathrm{~A}$ & 110.7 & -1.8 & -0.5 & -1.3 & -0.6 & -0.3 & -1.2 & 1.1 \\
\hline $4-6 B$ & 53.0 & -0.7 & -1.0 & 0.7 & -0.2 & -0.7 & -2.1 & -4.5 \\
\hline $4-8 \mathrm{~A}$ & 128.3 & -2.3 & -0.4 & 0.1 & 0.8 & -0.1 & -2.5 & -1.1 \\
\hline 4-9D & 230.6 & -3.1 & -0.2 & -0.3 & 2.0 & -0.1 & -0.8 & 30.5 \\
\hline
\end{tabular}


Table 6. (Continued).

\begin{tabular}{|c|c|c|c|c|c|c|c|c|}
\hline \multirow{3}{*}{$\begin{array}{l}\text { Cell } \\
\text { line }\end{array}$} & \multicolumn{8}{|c|}{ Signal change (RU) } \\
\hline & \multirow{2}{*}{$\begin{array}{l}\text { Immobilization } \\
\text { of antibody }\end{array}$} & \multirow{2}{*}{ HBS-EP } & \multicolumn{3}{|c|}{ Boiled samples } & \multicolumn{3}{|c|}{ Sonicated samples } \\
\hline & & & $\mathrm{SE}$ & $\mathrm{ST}$ & Mixture-1* & $\mathrm{SE}$ & ST & Mixture-1* \\
\hline $4-10 \mathrm{H}$ & 192.4 & -0.9 & 0.3 & -0.2 & -0.3 & 1.0 & -0.5 & 4.0 \\
\hline $4-11 \mathrm{C}$ & 196.0 & -4.4 & -0.5 & -1.1 & -1.0 & -0.5 & -2.0 & 2.4 \\
\hline $5-2 \mathrm{D}$ & 133.9 & -5.0 & -1.0 & -2.0 & -1.2 & -1.1 & -2.2 & -1.9 \\
\hline $5-6 \mathrm{C}$ & 108.2 & -2.5 & 0.5 & -1.1 & -1.0 & 10.3 & -1.6 & -2.8 \\
\hline $5-6 \mathrm{D}$ & 116.7 & -1.9 & -0.3 & -1.2 & -0.6 & 0.1 & -1.1 & -3.0 \\
\hline
\end{tabular}

*Mixture-1: the mixture of bacterial suspension of EC, EA, KP, and BC in HBS-EP.

Cell concentrations of SE and ST were approximately $10^{7} \mathrm{CFU} / \mathrm{ml}$, mixture- 1 was above $10^{8} \mathrm{CFU} / \mathrm{ml}$.

Table 7. Reactivity of the selected culture supernatants of hybridomas raised against SE against various bacteria by SPR biosensor

\begin{tabular}{|c|c|c|c|c|c|c|c|c|}
\hline \multirow{3}{*}{ Clone } & \multicolumn{8}{|c|}{ Signal change (RU) } \\
\hline & \multirow{2}{*}{$\begin{array}{l}\text { Immobilization } \\
\text { of antibody }\end{array}$} & \multirow{2}{*}{$\begin{array}{l}\text { HBS } \\
-\mathrm{EP}\end{array}$} & \multicolumn{3}{|c|}{ Boiled samples } & \multicolumn{3}{|c|}{ Sonicated samples } \\
\hline & & & $\mathrm{SE}$ & ST & Mixture-2* & $\mathrm{SE}$ & ST & Mixture-2* \\
\hline $1-4 \mathrm{~A}-3 \mathrm{~A}$ & 527.7 & -13.4 & 34.0 & 5.1 & 4.6 & 68.3 & 6.2 & 90.6 \\
\hline $1-4 \mathrm{~A}-8 \mathrm{G}$ & 597.5 & -10.9 & 53.0 & 26.3 & 24.5 & 95.2 & 22.5 & 173.4 \\
\hline $1-4 \mathrm{~A}-9 \mathrm{D}$ & 690.0 & -12.7 & 49.6 & 25.9 & 16.2 & 78.0 & 11.1 & 122.2 \\
\hline $1-4 \mathrm{~B}-2 \mathrm{~F}$ & 779.8 & -17.7 & 42.5 & 25.2 & 10.8 & 72.2 & 7.7 & 97.0 \\
\hline $1-4 \mathrm{~B}-4 \mathrm{C}$ & 932.4 & -19.9 & 48.1 & 24.9 & 11.6 & 73.1 & 7.3 & 99.0 \\
\hline $1-4 \mathrm{~B}-4 \mathrm{~F}$ & 895.9 & -22.4 & 35.4 & 15.9 & 3.6 & 60.6 & 0 & 71.3 \\
\hline $1-11 G-2$ & 255.7 & -11.7 & 0.4 & -0.7 & -5.2 & 42.7 & 7.6 & 36.1 \\
\hline $1-11 \mathrm{G}-7$ & 297.7 & -7.0 & 1.0 & 0.5 & -4.2 & 37.9 & 5.5 & 34.1 \\
\hline $1-11 G-8$ & 379.4 & -7.4 & 2.5 & 0.6 & -3.6 & 44.2 & 5.4 & 32.2 \\
\hline $2-8 \mathrm{H}-9 \mathrm{~B}$ & 651.3 & -10.3 & 51.0 & 15.6 & 14.6 & 81.3 & 15.0 & 96.5 \\
\hline $3-5 \mathrm{H}-1 \mathrm{~B}$ & 1172.3 & -19.0 & 73.9 & 15.3 & 9.6 & 31.5 & 39.6 & 120.3 \\
\hline $3-5 \mathrm{H}-3 \mathrm{~F}$ & 1238.2 & -22.5 & 68.8 & 5.9 & 0.5 & 27.5 & 29.3 & 101.0 \\
\hline $3-5 \mathrm{H}-5 \mathrm{H}$ & 1050.5 & -16.9 & 55.3 & 5.2 & 2.5 & 35.9 & 31.8 & 117.7 \\
\hline $3-7 \mathrm{~A}-7 \mathrm{H}$ & 242.5 & -14.7 & -6.7 & -8.6 & -7.3 & 19.7 & 6.7 & 46.9 \\
\hline $3-7 \mathrm{~A}-8 \mathrm{~B}$ & 1178.7 & -24.0 & 58.6 & -0.3 & 0.4 & 28.3 & 25.5 & 148.1 \\
\hline $3-7 \mathrm{~A}-11 \mathrm{E}$ & 110.9 & -10.9 & -2.3 & -2.7 & -3.9 & 20.8 & 5.4 & 47.5 \\
\hline $3-8 \mathrm{~F}-5 \mathrm{~B}$ & 449.6 & -11.8 & 2.2 & -7.1 & -4.0 & 45.7 & 4.2 & 41.9 \\
\hline $3-8 \mathrm{~F}-6 \mathrm{~B}$ & 451.6 & -10.8 & 1.8 & -4.9 & -3.9 & 47.4 & 4.9 & 39.2 \\
\hline $3-8 \mathrm{~F}-12 \mathrm{C}$ & 371.8 & -13.6 & 0.7 & -6.9 & -7.3 & 45.6 & 6.9 & 46.7 \\
\hline $3-10 \mathrm{~F}-2 \mathrm{D}$ & 304.0 & -6.8 & 2.0 & -3.2 & -4.4 & 37.5 & 9.0 & 38.5 \\
\hline $3-10 \mathrm{~F}-2 \mathrm{~F}$ & 445.8 & -9.3 & 4.8 & -5.4 & -4.2 & 48.5 & 6.0 & 42.4 \\
\hline $3-10 \mathrm{~F}-3 \mathrm{E}$ & 451.4 & -7.7 & 3.9 & -3.6 & -2.2 & 51.7 & 6.2 & 40.7 \\
\hline $5-6 \mathrm{C}-8 \mathrm{E}$ & 398.7 & -12.9 & -1.1 & -6.1 & -3.9 & 33.5 & 3.6 & 39.5 \\
\hline $5-6 \mathrm{C}-9 \mathrm{E}$ & 455.8 & -17.1 & -1.4 & -7.8 & -4.6 & 34.4 & 1.9 & 37.7 \\
\hline
\end{tabular}

*Mixture-2: the mixture of bacterial suspension of O157:H7, LM 1/2a, EC, EA, KP, and BC in HBS-EP.

Cell concentrations of SE and ST were approximately $10^{7} \mathrm{CFU} / \mathrm{ml}$, mixture-2 was approximately $10^{8} \mathrm{CFU} / \mathrm{ml}$.

ity of these clones against $L$. innocua and the mixture samples were not performed. The culture supernatants of the clones derived from the cell line $13 \mathrm{H} 9$ reacted strongly with sonicated LM 1/2a. Although the culture supernatants of these clones also reacted with sonicated L. innocua, the cross-reactivity of these clones against the sonicated mixture sample was very low. Among them, the culture supernatant of clone 13H9-2 showed the strongest response against sonicated LM 1/2a, and relative low reactivity to sonicated $L$. innocua and the mixture samples. Moreover, the clone-13H9-2-culture supernatant reacted strongly with boiled LM $4 \mathrm{~b}$ without crossreactivity against the other boiled samples. Hence, this clone was also selected for purification of anti-LM MAb. 
Table 8. Reactivity of culture supernatants of hybridoma cell lines raised against LM 1/2a against LM 1/2a determined by ELISA

\begin{tabular}{llll}
\hline Cell line & $\begin{array}{c}\text { Reactivity } \\
\left(\mathrm{A}_{510}\right)\end{array}$ & Cell line & $\begin{array}{c}\text { Reactivity } \\
\left(\mathrm{A}_{510}\right)\end{array}$ \\
\hline $1 \mathrm{C} 11$ & 0.938 & $4 \mathrm{H} 5$ & 0.628 \\
$1 \mathrm{~F} 2$ & 0.421 & $6 \mathrm{~F} 11$ & 0.153 \\
$1 \mathrm{~F} 10$ & 0.448 & $9 \mathrm{~B} 1$ & 0.361 \\
$2 \mathrm{~A} 6$ & 0.648 & $10 \mathrm{C} 6$ & 0.155 \\
$2 \mathrm{~A} 7$ & 0.678 & $11 \mathrm{D} 1$ & 0.239 \\
$2 \mathrm{~A} 8$ & 0.185 & $11 \mathrm{~F} 2$ & 0.297 \\
$2 \mathrm{~A} 11$ & 0.508 & $13 \mathrm{H} 9$ & 0.175 \\
$2 \mathrm{~F} 6$ & 0.646 & $16 \mathrm{~A} 6$ & 0.453 \\
$2 \mathrm{G} 2$ & 0.302 & $17 \mathrm{E} 9$ & 0.194 \\
$2 \mathrm{G} 9$ & 0.247 & $20 \mathrm{~B} 12$ & 0.139 \\
$2 \mathrm{G} 10$ & 0.168 & $21 \mathrm{E} 5$ & 0.178 \\
$2 \mathrm{G} 11$ & 0.102 & NC* & 0.021 \\
$3 \mathrm{~F} 10$ & 2.442 & PC** & 0.193 \\
\hline
\end{tabular}

*NC: the blank control with the coating buffer only.

**PC: the positive control with $300-$ fold diluted antiserum of immunized mouse.

\section{DISCUSSION}

Many attempts have been made to produce MAbs against O157:H7 (Jin et al., 2012; Li et al., 2010; Ryu et al., 2010; Yu et al., 2007; Zhao and Liu, 2005), SE (Brooks et al., 2012; Iankov et al., 2001; Iankov et al., 2004), and LM (Lin et al., 2006; Lin et al., 2009; Shim et al., 2007). In those studies, the selection of a specific antibody was conducted via ELISA, in which the cells were attached to plates followed by the binding of candidate antibodies and a tagged secondary antibody. Antibody selected via ELISA method, however, may not prove adequate for direct binding to cells, due to its large size (Joung et al., 2007). Joung et al. (2007) screened specific antibodies via direct binding to cells using an SPR biosensor and found that the screened antibody evidenced a significantly higher degree of sensitivity for direct detection of LM than the antibody selected via ELISA method.

In this study, MAbs against O157:H7, SE, and LM were screened by SPR biosensor in addition to indirect ELISA. MAbs obtained after screening by combined method showed a capacity to detect the target pathogens specifically by using SPR biosensor as well as ELISA method, while MAbs for LM showed cross-reactivity

Table 9. Reactivity of culture supernatants of hybridoma cell lines raised against LM 1/2a against various bacteria determined by SPR biosensor

\begin{tabular}{|c|c|c|c|c|c|c|c|c|c|c|c|c|}
\hline \multirow{3}{*}{$\begin{array}{l}\text { Cell } \\
\text { line }\end{array}$} & \multicolumn{12}{|c|}{ Signal change (RU) } \\
\hline & \multirow{2}{*}{$\begin{array}{l}\text { Immobilization } \\
\text { of antibody }\end{array}$} & \multirow{2}{*}{$\begin{array}{l}\mathrm{HBS} \\
-\mathrm{EP}\end{array}$} & \multicolumn{5}{|c|}{ Boiled samples } & \multicolumn{5}{|c|}{ Sonicated samples } \\
\hline & & & $\begin{array}{c}\mathrm{LM} \\
1 / 2 \mathrm{a}\end{array}$ & L. innocua & $\begin{array}{c}\mathrm{LM} \\
4 \mathrm{~b}\end{array}$ & $\begin{array}{r}\mathrm{LM} \\
1 / 2 \mathrm{~b}\end{array}$ & Mixture* & $\begin{array}{c}\mathrm{LM} \\
1 / 2 \mathrm{a}\end{array}$ & L. innocua & $\begin{array}{c}\mathrm{LM} \\
4 \mathrm{~b}\end{array}$ & $\begin{array}{r}\mathrm{LM} \\
1 / 2 \mathrm{~b}\end{array}$ & Mixture* \\
\hline $1 \mathrm{C} 11$ & 852.4 & -8.8 & -4.8 & -12.6 & -7.2 & -5.5 & -1.9 & 8.8 & -8.0 & -4.8 & -2.4 & 63.6 \\
\hline $1 F 2$ & 727.6 & -8.9 & -2.6 & -3.8 & 10.9 & -2.9 & -3.3 & 218.1 & 136.6 & 188.0 & 172.1 & 41.1 \\
\hline $1 \mathrm{~F} 10$ & 458.3 & -5.9 & -1.5 & -1.6 & 20.4 & -2.9 & -0.9 & 163.2 & 109.3 & 140.8 & 146.9 & 43.3 \\
\hline $2 \mathrm{~A} 6$ & 684.9 & -7.4 & -2.9 & -3.9 & 20.1 & -3.9 & -3.8 & 94.4 & 45.1 & 28.2 & 25.9 & 13.8 \\
\hline $2 \mathrm{~A} 7$ & 677.7 & -7.6 & -1.1 & -3.0 & 37.8 & -4.5 & 9.0 & 151.9 & 95.5 & 160.0 & 159.5 & 54.0 \\
\hline $2 \mathrm{~A} 8$ & 73.9 & -4.7 & -3.2 & -2.0 & -1.9 & -3.6 & -4.1 & 3.0 & 3.6 & 2.6 & 3.0 & 16.3 \\
\hline $2 \mathrm{~A} 11$ & 281.2 & -5.2 & -2.6 & -1.4 & 2.3 & -2.3 & -2.6 & 48.7 & 28.7 & 55.5 & 50.8 & 53.9 \\
\hline $2 \mathrm{~F} 6$ & 816.7 & -8.7 & -1.9 & -3.5 & 20.6 & -4.3 & -0.1 & 221.4 & 140.6 & 239.0 & 224.2 & 32.9 \\
\hline $2 \mathrm{G} 2$ & 617.4 & -6.8 & -2.2 & -2.3 & 2.2 & -3.6 & -1.4 & 29.8 & 4.1 & 16.3 & 12.7 & 31.2 \\
\hline 2G9 & 418.8 & -9.6 & -5.8 & -3.1 & -4.9 & -5.0 & -2.2 & 8.3 & 3.2 & 3.1 & 2.6 & 29.5 \\
\hline $2 \mathrm{G} 10$ & 557.6 & -8.7 & -2.9 & -2.6 & 5.5 & -3.5 & -5.7 & 86.6 & 60.6 & 87.5 & 88.6 & 24.2 \\
\hline $2 \mathrm{G} 11$ & 167.5 & -9.5 & -6.4 & -5.7 & -5.6 & -4.0 & -4.7 & -0.8 & -2.1 & 1.5 & 0.6 & 21.5 \\
\hline $3 \mathrm{~F} 10$ & 135.8 & -5.0 & -3.3 & -3.3 & -2.9 & -2.6 & -2.7 & 3.2 & 0.9 & 1.5 & 1.1 & 22.5 \\
\hline 4H5 & 508.6 & -6.4 & 0.0 & -0.5 & 8.5 & -3.2 & 0.5 & 421.5 & 545.4 & 293.7 & 68.5 & 70.8 \\
\hline $6 \mathrm{~F} 11$ & 315.8 & -8.4 & -2.1 & -3.8 & 12.8 & -3.0 & -3.3 & 3.8 & 2.2 & 5.2 & 4.6 & 24.8 \\
\hline 9B1 & 945.7 & -13.0 & -5.7 & -4.6 & 2.1 & -6.2 & -6.1 & 63.8 & 428.8 & 457.1 & -4.4 & 21.9 \\
\hline 10C6 & 341.2 & -5.9 & -1.0 & -1.2 & -3.7 & -1.9 & 1.2 & 17.8 & 14.9 & 13.4 & 12.8 & 59.8 \\
\hline 11D1 & 744.5 & -8.2 & 1.1 & -1.8 & 28.5 & -3.3 & 18.5 & 56.2 & 14.8 & 32.5 & 34.3 & 64.5 \\
\hline $11 \mathrm{~F} 2$ & 596.8 & -8.2 & -2.9 & -1.4 & -3.5 & -2.7 & -3.0 & 13.2 & 6.9 & 5.6 & 6.0 & 28.6 \\
\hline 13H9 & 738.1 & -5.1 & -3.4 & -3.1 & 19.6 & -3.0 & -1.3 & 228.9 & 142.8 & 248.5 & 225.9 & 32.7 \\
\hline $16 \mathrm{~A} 6$ & 736.0 & -6.7 & -6.4 & -5.8 & -4.9 & -4.3 & -2.2 & 0.3 & -0.9 & -0.9 & -1.8 & 3.8 \\
\hline 17E9 & 471.9 & -5.7 & -0.3 & -1.9 & 30.5 & -5.0 & 27.3 & 42.1 & 44.9 & 36.9 & 36.4 & 53.0 \\
\hline 20B12 & 360.6 & -5.1 & -1.4 & -1.3 & 8.3 & -3.7 & -3.2 & 77.8 & 64.8 & 82.7 & 80.3 & 40.3 \\
\hline $21 \mathrm{E} 5$ & 146.3 & -9.0 & -3.4 & -2.3 & -4.2 & -3.7 & -4.4 & 3.6 & 2.0 & -1.8 & 1.9 & 22.1 \\
\hline
\end{tabular}

*Mixture: the mixture of bacterial suspension of O157:H7, EC, EA, KP, SE, and BC in HBS-EP.

Cell concentrations of LM 1/2a, LM 1/2b, LM 4b, L. innocua and mixture were approximately $10^{8} \mathrm{CFU} / \mathrm{ml}$. 
Table 10. Reactivity of the selected culture supernatants of hybridoma cell lines raised against LM 1/2a against non-pathogenic Listeria spp. by SPR biosensor

\begin{tabular}{cccccccc}
\hline \multirow{2}{*}{ Cell line } & \multicolumn{7}{c}{ Signal change (RU) } \\
\cline { 2 - 8 } & $\begin{array}{c}\text { Immobilization } \\
\text { of antibody }\end{array}$ & HBS-EP & L. seelingeri & L. welshimeri & L. grayi & L. ivanovii & Mixture* \\
\hline 1F2 & 792.2 & -5.0 & 79.3 & 121.5 & 114.4 & 137.0 & 41.1 \\
1 F10 & 510.3 & -2.5 & 85.5 & 133.6 & 138.8 & 138.8 & 43.3 \\
2 A7 & 719.8 & -6.5 & 57.0 & 125.9 & 122.6 & 149.6 & 54.0 \\
2F6 & 1013.7 & -4.0 & 75.0 & 165.2 & 157.0 & 184.0 & 32.9 \\
13 H9 & 765.7 & -4.1 & 87.6 & 172.0 & 171.9 & 192.5 & 32.7 \\
\hline
\end{tabular}

*Mixture: the mixture of bacterial suspension of O157:H7, EC, EA, KP, SE, and BC in HBS-EP.

Cell concentrations of L. seelingeri, L. welshimeri, L. grayi, L. ivanovii and mixture were approximately $10^{8} \mathrm{CFU} / \mathrm{ml}$.

Table 11. Reactivity of the selected culture supernatants of hybridomas raised against LM 1/2a against various bacteria by SPR biosensor

\begin{tabular}{|c|c|c|c|c|c|c|c|c|c|c|}
\hline \multirow{3}{*}{ Clone } & \multicolumn{10}{|c|}{ Signal change (RU) } \\
\hline & \multirow{2}{*}{$\begin{array}{l}\text { Immobilization } \\
\text { of antibody }\end{array}$} & \multirow{2}{*}{ HBS-EP } & \multicolumn{4}{|c|}{ Boiled samples } & \multicolumn{4}{|c|}{ Sonicated samples } \\
\hline & & & LM 1/2a & L. innocua & $\mathrm{LM} 4 \mathrm{~b}$ & Mixture* & LM $1 / 2 \mathrm{a}$ & L. innocua & $\mathrm{LM} 4 \mathrm{~b}$ & Mixture* \\
\hline $2 \mathrm{~F} 6-2$ & 766.6 & -2.7 & -1.9 & & -1.4 & & 0.1 & & -0.5 & \\
\hline $2 \mathrm{~F} 6-3$ & 505.7 & 0.0 & 0.0 & & 2.0 & & 5.6 & & 2.8 & \\
\hline $2 \mathrm{~F} 6-4$ & 594.9 & -0.2 & -0.5 & - & 6.7 & - & 4.8 & - & 1.7 & - \\
\hline $2 \mathrm{~F} 6-5$ & 483.5 & -2.1 & -1.1 & & -1.1 & & 1.0 & & 0.4 & \\
\hline $2 \mathrm{~F} 6-6$ & 555.2 & -1.3 & -0.8 & & 4.3 & & 5.7 & & 2.9 & \\
\hline $2 \mathrm{~F} 6-7$ & 701.3 & -3.3 & 0.8 & 5.5 & 16.9 & 4.7 & 8.9 & -2.5 & -0.5 & 9.6 \\
\hline $2 \mathrm{~F} 6-8$ & 295.0 & -4.6 & 0.9 & & -3.0 & & 2.2 & & 1.0 & \\
\hline $2 \mathrm{~F} 6-9$ & 458.6 & -0.7 & 0.3 & & -0.1 & & 6.8 & & 3.0 & \\
\hline $2 \mathrm{~F} 6-10$ & 449.0 & -0.7 & 0.9 & & 0.2 & & 8.3 & & 3.6 & \\
\hline $2 \mathrm{~F} 6-11$ & 306.4 & -5.7 & -1.9 & & -3.1 & & 2.1 & & 1.6 & \\
\hline $2 \mathrm{~F} 6-12$ & 342.7 & -1.6 & -0.5 & & -0.2 & & 5.4 & & 2.3 & \\
\hline $2 \mathrm{~F} 6-13$ & 437.5 & -3.6 & -1.5 & - & -1.5 & _- & 1.3 & _- & 2.8 & - \\
\hline $2 \mathrm{~F} 6-14$ & 384.7 & -5.8 & -1.4 & & -1.5 & & 3.5 & & 2.2 & \\
\hline $2 \mathrm{~F} 6-15$ & 121.6 & -0.4 & 0.0 & & 0.7 & & 6.1 & & 5.4 & \\
\hline $2 \mathrm{~F} 6-16$ & 315.7 & -7.9 & -2.6 & & -2.5 & & 4.1 & & 0.3 & \\
\hline $2 \mathrm{~F} 6-18$ & 546.1 & -2.5 & -0.5 & & 1.7 & & 9.0 & & 3.8 & \\
\hline 13H9-1 & 812.1 & -0.1 & 0.8 & -1.3 & 10.8 & -4.8 & 242.1 & 196.5 & 49.3 & 2.3 \\
\hline 13H9-2 & 718.6 & -4.2 & 0.1 & 0.1 & 11.2 & -3.3 & 224.9 & 172.7 & 46.6 & 2.7 \\
\hline 13H9-3 & 525.4 & -4.9 & -1.6 & 1.5 & 5.7 & -2.0 & 175.4 & 138.0 & 31.1 & 3.2 \\
\hline $13 \mathrm{H} 9-4$ & 650.4 & -4.5 & -0.9 & 0.0 & 8.5 & -2.9 & 211.7 & 169.2 & 45.9 & 6.6 \\
\hline $13 \mathrm{H} 9-5$ & 517.0 & -2.5 & 0.1 & 0.8 & 8.7 & -1.8 & 169.3 & 133.5 & 32.0 & 6.1 \\
\hline 13Н9-6 & 646.7 & -4.2 & -0.2 & 0.9 & 9.8 & -2.4 & 213.1 & 157.8 & 35.0 & 5.2 \\
\hline $13 \mathrm{H} 9-7$ & 656.9 & -5.0 & -0.4 & 0.6 & 8.9 & -3.5 & 207.1 & 164.9 & 41.7 & 4.0 \\
\hline 13H9-8 & 574.1 & -3.8 & 0.7 & 0.6 & 9.8 & -2.6 & 190.6 & 144.7 & 33.5 & 3.5 \\
\hline 13H9-9 & 612.0 & -4.2 & 0.1 & -0.3 & 10.0 & -3.2 & 195.1 & 146.5 & 37.0 & 6.3 \\
\hline 13H9-10 & 673.8 & -3.8 & 0.1 & 0.8 & 10.4 & -4.0 & 212.5 & 156.2 & 40.4 & 5.4 \\
\hline 13H9-11 & 654.7 & -6.3 & -0.9 & 1.1 & 9.4 & -3.8 & 216.6 & 163.1 & 38.7 & 5.1 \\
\hline 13H9-12 & 558.8 & -5.2 & -0.7 & 1.0 & 8.8 & -1.5 & 179.9 & 146.2 & 37.6 & 4.3 \\
\hline 13H9-13 & 639.9 & -4.0 & -0.4 & 0.6 & 10.3 & -2.9 & 203.2 & 159.7 & 36.2 & 3.0 \\
\hline 13H9-14 & 583.2 & -7.6 & -1.7 & 0.5 & 8.1 & -1.8 & 182.7 & 151.6 & 32.1 & 3.1 \\
\hline 13H9-15 & 629.3 & -6.7 & -0.3 & 1.4 & 8.6 & -1.5 & 167.0 & 165.1 & 31.6 & 3.2 \\
\hline
\end{tabular}

-, not done. Cross-reactivity of these clones with L. innocua and mixture were not performed as they had almost no reactivity with boiled or sonicated LM samples.

*Mixture: the mixture of bacterial suspension of O157:H7, EC, EA, KP, SE, and BC in HBS-EP

Cell concentrations of LM 1/2a, LM 4b, L. innocua and mixture were approximately $10^{8} \mathrm{CFU} / \mathrm{ml}$. 
against boiled $L$. innocua or sonicated $L$. innocua. Cross-reactivity arises because the non-target bacterium shares an epitope in common with the target pathogen or because it has an epitope that is structurally similar to that of the target pathogen (Zhang et al., 2014). In previous studies (Bhunia et al., 1991; Bubert et al., 1994; Kathariou et al., 1994; Sølve et al., 2000), a similar difficulty with a cross-reaction to $L$. innocua was also reported in the preparation of antibody specific to LM.

Further work is needed to determine detection sensitivity and specificity of the purified MAbs. The developed MAbs with high sensitivity and specificity will be also available for multichannel SPR biosensor. These MAbs are expected to be helpful in improving lower detection limits for O157:H7, SE, and LM in food samples by using SPR biosensor.

\section{AUTHOR CONTRIBUTIONS}

X. G. Zhang designed the study, performed the preparation of antigens, ELISA and SPR experiments, analyzed the data and wrote the paper. S. Tsuji, H. Kitaoka, and M. Tamai participated in the estimation of antibodies by ELISA and SPR. H. Kobayashi participated in the design of the study and performed a part of ELISA and SPR experiments. K. Honjoh participated in the design of the study. T. Miyamoto designed the study, supervised the work, wrote the paper and provided facilities and resources. All authors assisted in editing of the manuscript and approved the final version.

\section{ACKNOWLEDGEMENTS}

This work was partly supported by the National Natural Science Foundation of China (No. 31701713) and the Scientific Research Fund of Jilin Provincial Science and Technology Department (No. 20160520041JH). The authors declare that there is no conflict of interest.

\section{REFERENCES}

Bhunia, A. K., P. H. Ball, A. T. Fuad, B. W. Kurz, J. W. Emerson and M. G. Johnson 1991 Development and characterization of a monoclonal antibody specific for Listeria monocytogenes and Listeria innocua. Infect. Immun., 59: 3176-3184

Brooks, B. W., C. L. Lutze-Wallace, J. Devenish, M. Elmufti and T. Burke 2012 Development of an antigen-capture monoclonal antibody-based enzyme-linked immunosorbent assay and comparison with culture for detection of Salmonella enterica serovar Enteritidis in poultry hatchery environmental samples. $J$. Vet. Diagn. Invest., 24: 509-515

Bubert, A., P. Schubert, S. Kohler, R. Frank and W. Goebel 1994 Synthetic peptides derived from the Listeria monocytogenes p60 protein as antigens for the generation of polyclonal antibodies specific for secreted cell-free L. monocytogenes p60 proteins. Appl. Environ. Microbiol., 60: 3120-3127

Hochel, I., D. Slavícková, D. Viochna, J. Škvor and I. Steinhauserová 2007 Detection of Campylobacter species in foods by indirect competitive ELISA using hen and rabbit antibodies. Food Agric. Immunol., 18: 151-167

Iankov, I. D., D. P. Petrov, I. V. Mladenov, I. H. Haralambieva, R. Ivanova, L. Sechanova and I. G. Mitov 2001 Monoclonal anti- bodies of IgA isotype specific for lipopolysaccharide of Salmonella enteritidis: Production, purification, characterization and application as serotyping reagents. FEMS Microbiol. Lett., 196: $215-221$

Iankov, I. D., D. P. Petrov, I. V. Mladenov, I. H. Haralambieva, O. K. Kalev, M. S. Balabanova and I. G. Mitov 2004 Protective efficacy of IgA monoclonal antibodies to $\mathrm{O}$ and $\mathrm{H}$ antigens in a mouse model of intranasal challenge with Salmonella enterica serotype Enteritidis. Microb. Infect., 6: 901-910

Jin, M., J. Lang, Z. Q. Shen, Z. L. Chen, Z. G. Qiu, X. W. Wang and J. W. Li 2012 A rapid subtractive immunization method to prepare discriminatory monoclonal antibodies for food E. coli O157:H7 contamination. PLOS ONE, 7:

Joung, H. A., W. B. Shim, D. H. Chung, J. Ahn, B. H. Chung, H. S. Choi, S. D. Ha, K. S. Kim, K. H. Lee, C. H. Kim, K. Y. Kim and M. G. Kim 2007 Screening of a specific monoclonal antibody against and detection of Listeria monocytogenes whole cells using a surface plasmon resonance biosensor. Biotechnol. Bioprocess Eng., 12: 80-85

Karoonuthaisiri, N., R. Charlermroj, M. J. Morton, M. OplatowskaStachowiak, I. R. Grant and C. T. Elliott 2014 Development of a M13 bacteriophage-based SPR detection using Salmonella as a case study. Sens Actuators B: Chem, 190: 214-220

Kathariou, S., C. Mizumoto, R. D. Allen, A. K. Fok and A. A. Benedict 1994 Monoclonal antibodies with a high degree of specificity for Listeria monocytogenes serotype 4b. Appl. Environ. Microbiol., 60: 3548-3552

Li, G., J. Hong, G. Huo and X. Ren 2010 Monoclonal antibodies against Stx1B subunit of Escherichia coli O157:H7 distinguish the bacterium from other bacteria. Lett. Appl. Microbiol., 51: 499-503

Lin, M., S. Armstrong, J. Ronholm, H. Dan, M. E. Auclair, Z. Zhang and X. Cao 2009 Screening and characterization of monoclonal antibodies to the surface antigens of Listeria monocytogenes serotype 4b. J. Appl. Microbiol., 106: 1705-1714

Lin, M., D. Todoric, M. Mallory, B. S. Luo, E. Trottier and H. Dan 2006 Monoclonal antibodies binding to the cell surface of Listeria monocytogenes serotype 4b. J. Med. Microbiol., 55: 291299

Löfås, S. and B. Johnsson 1990 A novel hydrogel matrix on gold surfaces in surface plasmon resonance sensors for fast and efficient covalent immobilization of ligands. J. Chem. Soc., Chem. Commun, 21: 1526-1528

Meeusen, C. A., E. C. Alocilja and W. N. Osburn 2005 Detection of E. coli O157:H7 using a miniaturized surface plasmon resonance biosensor. Trans. ASAE, 48: 2409-2416

Rich, R. L. and D. G. Myszka 2001 BIACORE J: A new platform for routine biomolecular interaction analysis. J. Mol. Recognit., 14: $223-228$

Ryu, H. J., J. S. Kim, K. Kim, B. R. Nam, M. Nam, W. B. Shim, N. Kim, Y. J. Cho and D. H. Chung 2010 Production of monoclonal antibody against Escherichia coli O157:H7 and development of enzyme linked immunosorbent assay. Korean J. Food Sci. Technol., 42: 329-334

Shim, W. B., J. G. Choi, J. Y. Kim, Z. Y. Yang, K. H. Lee, M. G. Kim, S. D. Ha, K. S. Kim, K. Y. Kim, C. H. Kim, K. S. Ha, S. A. Eremin and D. H. Chung 2007 Production of monoclonal antibody against Listeria monocytogenes and its application to immunochromatography strip test. J. Microbiol. Biotechnol., 17: 1152-1161

Sølve, M., J. Boel and B. Nørrung 2000 Evaluation of a monoclonal antibody able to detect live Listeria monocytogenes and Listeria innocua. Int. J. Food Microbiol., 57: 219-224

Subramanian, A., J. Irudayaraj and T. Ryan 2006 A mixed selfassembled monolayer-based surface plasmon immunosensor for detection of E. coli O157:H7. Biosens. Bioelectron., 21: 9981006

Tanaka, H., S. Yan, N. Miura and Y. Shoyama 2003 Preparation of anti-2,4-dichlorophenol and 2,4-dichlorophenoxyacetic acid monoclonal antibodies. Cytotechnology, 42: 101-107

Tawil, N., E. Sacher, R. Mandeville and M. Meunier 2012 Surface plasmon resonance detection of $\mathrm{E}$. coli and methicillin-resistant 
S. aureus using bacteriophages. Biosens. Bioelectron., 37: 24-29

Taylor, A. D., Q. Yu, S. Chen, J. Homola and S. Jiang 2005 Comparison of E. coli O157:H7 preparation methods used for detection with surface plasmon resonance sensor. Sens Actuators B: Chem, 107: 202-208

Velusamy, V., K. Arshak, O. Korostynska, K. Oliwa and C. Adley 2010 An overview of foodborne pathogen detection: In the perspective of biosensors. Biotechnol. Adv., 28: 232-254

Wei, D., O. A. Oyarzabal, T. S. Huang, S. Balasubramanian, S. Sista and A. L. Simonian 2007 Development of a surface plasmon resonance biosensor for the identification of Campylobacter jejuni. J. Microbiol. Methods, 69: 78-85
Yu, S., P. Luo, H. Z. Chen, H. X. Li and X. H. Mao 2007 Preparation and characterization of monoclonal antibody against Enterohemorrhagic Escherichia coli O157:H7 EspA. Xi Bao Yu Fen Zi Mian Yi Xue Za Zhi, 23: 657-659

Zhang, X. G., H. Kitaoka, S. Tsuji, M. Tamai, H. Kobayashi, K. Honjoh and T. Miyamoto 2014 Development of a Simultaneous Detection Method for Foodborne Pathogens Using Surface Plasmon Resonance Biosensors. Food Sci. Technol. Res, 20: $317-$ 325

Zhao, Z. J. and X. M. Liu 2005 Preparation of monoclonal antibody and development of enzyme-linked immunosorbent assay specific for Escherichia coli $\mathrm{O} 157$ in foods. Biomed. Environ. Sci., 18: 254-259 